\title{
Iron Chelation and Iron Reducing Activity of Tissue Cultured and Tissue Culture Derived Mentha Spp.
}

\author{
Akash Deep $^{1 *}$, Pooja Rana ${ }^{2}$, Giridhar Soni ${ }^{3}$ \\ ${ }^{1}$ Department of Biochemistry, Punjab Agricultural University, Ludhiana, Punjab, India. \\ ${ }^{2}$ Department of Biotechnology, Modern College of Arts, Science and Commerce, Ganeshkhind, Pune, India. \\ ${ }^{3}$ Professor (retired), Department of Biochemistry, Punjab Agricultural University, Ludhiana, Punjab, India.
}

\begin{tabular}{|c|c|}
\hline ARTICLE INFO & ABSTRACT \\
\hline Article history: & \multirow{5}{*}{$\begin{array}{l}\text { The present study was carried out to study the effect of maturity of tissue cultured and tissue cultured derived } \\
\text { Mentha spp on iron chelation and iron reducing potential. Mentha sps. selected for the study were Mentha } \\
\text { piperita (PPR 611), Mentha arvensis (SH) and Mentha spicata (SPR-8). Methanolic extracts of selected Mentha } \\
\text { spp were prepared and total phenolic and flavonoid contents were determined in tissue cultured(TC) and tissue } \\
\text { culture derived plantlets ( } \mathrm{TC}_{\mathrm{o}} \text { and } \mathrm{TC}_{1} \text { ). Furthermore, a comparison of chelation of ferrous ions and iron } \\
\text { reducing power of extracts was made in the three species. Total phenol content increased in time dependent } \\
\text { manner and was found to be more in tissue culture derived plantlets ( } \mathrm{TC}_{0} \text { and } \mathrm{TC}_{1} \text { ) in all the three species } \\
\text { compared to tissue cultured plants (TC). The phenols were found to be highest in SPR- } 8 \text { plants followed by } \\
\text { PPR } 611 \text {. On the contrary, flavonoid content decreased over growth period in all Mentha spp. Also PPR } 611 \\
\text { showed higher content of flavonoids compared to other species. The difference in production of these secondary } \\
\text { metabolites may be due to culture induced variations in biosynthetic pathways. The iron reducing potential of } \\
\text { tissue culture derived plants also increased with increase in development period and SPR-8 showed more } \\
\text { promising results. Tissue cultured raised and tissue culture derived plantlets of SPR-8 had better iron chelation } \\
\text { property and the activity decreased in tissue cultured derived plantlets with an increase in development period. }\end{array}$} \\
\hline Received on: $31 / 10 / 2016$ & \\
\hline Accepted on: 05/03/2017 & \\
\hline Available online: $30 / 05 / 2017$ & \\
\hline $\begin{array}{l}\text { Key words: } \\
\text { Mentha, reducing power, } \\
\text { tissue culture, iron chelation, } \\
\text { development periods. }\end{array}$ & \\
\hline
\end{tabular}

\section{INTRODUCTION}

Herbs have been identified as source of various phytochemicals, many of which possess important antioxidant activity. Mentha is a genus of aromatic perennial herbs belonging to the family Lamiaceae, distributed mostly in temperate and sub-temperate regions of the world. Most of the commercially important mints are hybrids or amphiploids. The Lamiaceae family (Labiatae) is one of the largest and most distinctive families of flowering plants, with about 220 genera and almost

\footnotetext{
* Corresponding Author

Akash Deep, Adjunct Faculty, Center for Academic Success(CAS), Union, Kean University, New Jersey, U.S.A. Phone: +1(908)787-9823

Email:akash_bhagirath@yahoo.in
}

4000 species worldwide. It is one of the most diverse and widespread plant families in terms of ethnomedicine (Naghibi et al., 2005).

Members of this genus are the most important sources of essential oil production in the world. It has been estimated that the annual production of oils from the three Mentha spp, namely, peppermint ( $M$. piperita L.), cornmint (M. arvensis L.) and spearmint (M. spicata), is in excess of 23,000 metric tons with a value exceeding $\$ 400$ million. This makes them one of the most economically important essential oils producers (Lawerence, 2006). The antioxidant activity of plant extracts is widely used in the food industry as potential inhibitors of lipid per oxidation, which become important and interesting object of research because of the increasing usage of natural antioxidants (Scherer and Godoy, 2009; Grul'ova et al., 2012). 
Phenolic compounds, also known as polyphenol antioxidants, which include flavonoids and phenolic acids, are found naturally in spearmint plants. Phenolic compounds inhibit lipid peroxidation, scavenge free radicals, iron and copper ions. Phenolic compounds exhibit a range of biological activities, including anticancer, antibacterial, antioxidant and antiinflammatory properties ( $\mathrm{Lu} \mathrm{Y}$ and Foo, 2002).

Mentha is known to be endowed with a variety of biological and pharmacological properties due to the high content of secondary metabolites (Choudhury et al., 2006). Previously antiallergic (Yaamamura et al., 1998), anti-oxidant (Kannat et al., 2007), anti-platelet (Togolini et al., 2006), anti-proliferative (Manasroi et al., 2006), chemo-preventive (Saleem et al., 2000), $\mathrm{H}_{2} \mathrm{O}_{2}$ scavenging (Kumar and Chattopadhyay 2007) and antimutagenic (Yu et al., 2004) activity of this plant had been reported. This plant also possesses anti-Candida and also radio protective activity against gamma radiation (Marta et al., 2005; Ganesh and Manjeshwar, 2002).

Because of the possible toxicities of the synthetic antioxidants, butylated hydroxyanisole (BHA) and butylated hydroxytoluene (BHT), increasing attention has been directed toward natural antioxidants (Namiki 1990), especially plant phytochemicals. The antioxidant potential of different cultivars of tissue cultured Mentha has been shown in a number of in vitro studies (Akashdeep et al., 2011, 2014). They are capable of direct chain-breaking antioxidant action by radical scavenging. In addition to being capable of scavenging non-physiological radicals such as DPPH' and ABTS ' (Payet et al., 2005; Cai et al., 2006), they are capable of scavenging a variety of reactive species such as superoxide, hydroxyl, peroxyl radicals and hypochlorous acid (Halliwell et al., 2005). They can also suppress the formation of reactive oxygen speciesby chelating transition metal ions capable of catalyzing oxidative reactions (Mira et al., 2002).

The application of plant tissue culture has gained major industrial importance in three main areas such as breeding and genetics (Julia and Claudia 2012), as model systems for plant biochemistry and pathology and production of secondary metabolites (Tisserat and Vaughn 2008). Therefore, the application of the tissue culture technique will be very useful in order to conserve and future augmentation of the metabolites present in these very useful medicinal plants. Moreover, antioxidant potential of herbs varies greatly with varietal differences, cultivation conditions and environment (Dragland et al., 2003).

Therefore, the study was planned to study the effect of maturity of tissue cultured (TC) and tissue culture derived $\left(\mathrm{TC}_{0}\right.$ and $\left.\mathrm{TC}_{1}\right)$ Mentha spp on phenolic content, flavonoid content, iron chelation and iron reducing potential.

\section{MATERIAL AND METHODS}

\section{Plant Material}

The Mentha spp viz. Mentha piperita (PPR 611), Mentha arvensis (SH), Mentha spicata (SPR-8), selected for present studies, were obtained from the School of Agricultural Biotechnology, PAU, Ludhiana.

\section{Micropropagation of Mentha species \\ Preparation of culture medium, Inoculation (culturing) and propagation}

Leaf segments from healthy plants were used in present study. The explants were thoroughly washed in running tap water and surface sterilized with mercuric chloride solution $\left(\mathrm{HgCl}_{2}\right)$ $(0.1 \%)$ for five minutes, followed by washing with sterile double distilled water to remove traces of $\mathrm{HgCl}_{2}$. The explants of Mentha were inoculated aseptically into culture vessel containing Murashige and Skoog medium (1962). Nutrient medium was homogenized by boiling and by continuous stirring before adding agar. The $\mathrm{pH}$ of the medium was adjusted as 5.8 prior to addition of agar by using $0.1 \mathrm{~N} \mathrm{NaOH}$ and $0.1 \mathrm{~N} \mathrm{HCl}$. After adding, 2,4 dichlorophenoxyacetic $\operatorname{acid}(2,4 \mathrm{D})(1 \mathrm{mg} / \mathrm{l})$ in combination with Benzylamino purine (BAP) $(0.5 \mathrm{mg} / \mathrm{l})$, about $15-20 \mathrm{ml}$ of media was dispensed into each culture tube. After autoclaving, the culture vials were kept inside the inoculation chamber. The explants(leaves) of Mentha spp were inoculated aseptically into culture vessel. These cultures were incubated at a temperature of $25 \pm 2{ }^{\circ} \mathrm{C}$ with relative humidity $(60 \%-80 \%)$. Cultures were given florescent light (3000-5000 Lux), $16 \mathrm{~h}$ light/8 h dark regimes.

After one month of culturing, tissue cultured samples (TC) of all the three Mentha spp were shifted to soil in glass house for further development and were named as $\mathrm{TC}_{0}$. After 30 days, cutting $(3 \mathrm{~cm})$ of few plants of $\mathrm{TC}_{0}$ was done and these cuttings were replanted in soil in glass house and were called $\mathrm{TC}_{1}$. Both these generations of tissue cultured derived plants $\left(\mathrm{TC}_{0}\right.$ and $\left.\mathrm{TC}_{1}\right)$ were grown for the three months. Samples were collected from tissue culture (TC) and tissue culture derived plants ( $\mathrm{TC}_{0}$ and $\left.\mathrm{TC} 1\right)$ for further analysis.

\section{Preparation of plant extract}

The plant material (leaves) $2 \mathrm{~g}$ was crushed with methanol $(25 \mathrm{ml})$ and shaken overnight at $30{ }^{\circ} \mathrm{C}$. Extracts were filtered and residues were re-extracted twice under same conditions using same solvent. Solvents were removed from the combined filtrates under vacuum at $45^{\circ} \mathrm{C}$ in Buchi rotary evaporator and extracts were stored at $-20{ }^{\circ} \mathrm{C}$ until further use.

\section{Estimation of phenols and flavonoids}

The extracts were analyzed for total phenols and flavonoids and the results were expressed as $\mathrm{mg} / \mathrm{g}$ dry weight of leaves. Total phenolic compound contents were determined by the Folin-Ciocalteau assay (Ebrahimzadeh et al., 2008 a, b). The extract samples $(0.5 \mathrm{ml})$ were mixed with $2.5 \mathrm{ml}$ of $0.2 \mathrm{~N}$ FolinCiocalteau reagent (Sigma-Aldrich) for $5 \mathrm{~min}$ and $2.0 \mathrm{ml}$ of $75 \mathrm{~g} / \mathrm{l}$ sodium carbonate were then added. The absorbance of reaction was measured at $760 \mathrm{~nm}$ with a double beam Perkin Elmer UV/Visible spectrophotometer (USA) after $2 \mathrm{~h}$ of incubation at room temperature. The samples were prepared in triplicates and mean value of absorbance was obtained. The standard curve was 
prepared using 50 to $250 \mathrm{mg} / \mathrm{ml}$ solutions of gallic acid in methanol-water $(1: 1, \mathrm{v} / \mathrm{v})$. Total phenol values are expressed in terms of $\mathrm{mg}$ gallic acid equivalents per $\mathrm{g}$ dry weight (mg GAE/g DW), which is a common reference phenolic compound.

Flavonoid content of tissue cultured and tissue culture derived plant extracts were determined by the method of Chang $e t$ al., 2002. $0.5 \mathrm{~mL}$ solution of each plant extracts (at $10 \% \mathrm{w} / \mathrm{v}$ ) in methanol were separately mixed with $1.5 \mathrm{~mL}$ of methanol, $0.1 \mathrm{~mL}$ of $10 \%$ aluminum chloride, $0.1 \mathrm{ml}$ of $1 \mathrm{M}$ potassium acetate, and $2.8 \mathrm{~mL}$ of distilled water, and left at room temperature for $30 \mathrm{~min}$. The absorbance of the reaction mixture was measured at $415 \mathrm{~nm}$ with a double beam Perkin Elmer UV/Visible spectrophotometer (USA). Catechin was used as standard to make calibration curve. Total flavonoid content of mint plants was expressed as milligrams catechin equivalentsper gdry weight (mg CEE/gDW).

\section{Evaluation of antioxidant potential using in vitro models Metal chelating activity}

The chelating effect on ferrous ions was determined according to the method of Dinis (1994) with some modifications. The method is based upon the ability of the extract to compete with ferrozine for ferrous ions. The various extracts $(0.25 \mathrm{ml})$ were mixed with $1.75 \mathrm{ml}$ of methanol and $0.25 \mathrm{ml}$ of $250 \mathrm{mM} \mathrm{FeCl}_{2}$. This was followed by the addition of $0.25 \mathrm{ml}$ of $2 \mathrm{mM}$ ferrozine, and was allowed to equilibrate for $10 \mathrm{~min}$ at room temperature. The purple coloration formed was read at $562 \mathrm{~nm}$. The control contained $80 \%$ methanol instead ofthe extract. The chelating activity was calculated according to the equation given below.

Metal chelating activity $(\%)=((\mathrm{A} 0-\mathrm{As}) / \mathrm{As}) \times 100$

\section{Iron reducing activity}

Iron reducing power of extract was determined by the method of Oyaizu (1986). Different concentrations of various extracts in $1 \mathrm{ml}$ of distilled water were mixed with phosphate buffer $(2.5 \mathrm{ml}, 0.2 \mathrm{M}, \mathrm{pH}$ 6.6) and potassium ferricyanide $\left(\mathrm{K}_{3} \mathrm{Fe}(\mathrm{CN})_{6}\right)(2.5 \mathrm{ml}, 1 \%)$. The mixture was incubated at $50^{\circ} \mathrm{C}$ for $20 \mathrm{~min}$ and $2.5 \mathrm{ml}$ of trichloroacetic acid (10\%) was added to the mixture, which was then centrifuged for $10 \mathrm{~min}$ at $1000 \mathrm{~g}$. The upper layer of solution $(2.5 \mathrm{ml})$ was mixed with distilled water (2.5 ml) and $\mathrm{FeCl}_{3}(0.5 \mathrm{ml}, 0.1 \%)$. The amount of iron(II)ferricyanide complex formed was determined by measuring the formation of Perl's Prussion blue at $700 \mathrm{~nm}$ after 10 minutes. Increase in absorbance of the reaction mixture indicated the reducing power. Ascorbic acid was used as standard.

\section{Statistical analysis}

All the data was reported as mean \pm standard deviation of three replicates.

\section{RESULTS AND DISCUSSION}

\section{Phenolics and flavonoid content of Mentha spp}

Phytochemical constituents in the plant samples are known to be biologically active compounds and they are responsible for different activities such as antioxidant, antimicrobial, antifungal, and anticancer (Hossain and Nagooru, 2011; Suresh and Nagarajan, 2009). Phenolics have antioxidative, antidiabetic, anticarcinogenic, antimicrobial, antiallergic, antimutageneic, and antiinflammatory activities (Saidu et al., 2012; Sasikumar et al., 2010).

Flavonoids also have antioxidant property as they inhibit oxidative and hydrolytic enzymes, have impact on radical scavenging, anti-inflammatory and anti-cancerous activity (Liu et al., 2008; Alsabri et al., 2013). Total phenolic content of methanolic extracts of mint plants was evaluated using Folin Ciocalteau reagent and results were expressed as mg Gallic Acid (GA) equivalents per $g$ dry weight. It is evident from the result that total phenol content of TC plantlets was highest in SPR-8 (3.20 $\mathrm{mg} / \mathrm{GAE})$ followed by $\mathrm{SH}(1.16 \mathrm{mg} / \mathrm{GAE})$ and PPR $611(0.67$ $\mathrm{mg} / \mathrm{GAE})$. Tissue culture derived plants $\left(\mathrm{TC}_{0}\right.$ and $\left.\mathrm{TC}_{1}\right)$ had substantially higher content of total phenols as compared to TC plantlets.

The total phenol content increased over the growth period of tissue culture derived $\left(\mathrm{TC}_{0}\right.$ and $\left.\mathrm{TC}_{1}\right)$ plants in all the three species and was found to be highest in $\mathrm{TC}_{1}$ SPR- 8 plants (7.3 $\mathrm{mg} / \mathrm{GAE}$ ) at 3 months of development period followed by PPR 611(mg/GAE). Phenols are very important plant constituents; they show high scavenging ability of free radicals due to their hydroxyl group. Therefore, the phenolic content of plants may contribute directly to their antioxidant action (Tosun et al., 2009). The high correlation between the values of phenol concentration in plant extracts and antioxidant activity is a well-documented study (Borneo et al., 2008; Katalinic et al., 2004).

The secondary plant metabolites flavonoids show significant antioxidant and chelating properties, which arebased on the structure and substitution pattern of hydroxyl groups (Sharififar, 2008). Tissue culture samples of all the three species of Mentha had higher content of flavonoids as well $(1.85,0.71$ and $3.8 \mathrm{mg}$ CEE for PPR 611, SH and SPR 8 respectively) in comparison to $\mathrm{TC}_{0}$ and $\mathrm{TC}_{1}$ samples at either of the growth period. Further, there was gradual decrease in flavonoid content in $\mathrm{TC}$ derived plants $\left(\mathrm{TC}_{0}\right.$ and $\left.\mathrm{TC}_{1}\right)$ over a growth period of three months in all the Mentha spp. Like total phenols, the flavonoid content of SPR-8 was found to be higher than other species.

However, in TC derived plants $\left(\mathrm{TC}_{0}\right.$ and $\left.\mathrm{TC}_{1}\right)$, PPR 611 had higher content of flavonoids as compared to that of SPR-8 and $\mathrm{SH}$. Therefore, it can be concluded that tissue culture derived plants may vary from the parent plant in the content of secondary metabolites.

An increase in total phenols and flavonoids in TC derived plantlets points out the suitability of plant tissue culture in enhancing the yield of particular phytochemicals. A number of factors like biochemical, physiological and environmental may affect production of secondary metabolites, therefore, a marked difference in secondary metabolites may be due to culture induced variations in different biosynthetic pathways. 
Table 1: Total phenol(mg GAE/g DW) and flavonoids(mg CEE/g DW) content of Menthaspp at different development periods.

\begin{tabular}{|c|c|c|c|c|}
\hline Stage & Development period (month) & Mentha piperita PPR 611 & Menthaarvensis SH & Mentha spicata SPR 8 \\
\hline \multicolumn{5}{|c|}{ (Total phenol mg GAE/g DW) } \\
\hline TC & & $0.67 \pm 0.03$ & $1.16 \pm 0.03$ & $3.20 \pm 0.02$ \\
\hline \multirow[t]{3}{*}{$\mathrm{TC}_{0}$} & 1 & $3.70 \pm 0.03$ & $1.50 \pm 0.03$ & $4.36 \pm 0.02$ \\
\hline & 2 & $4.60 \pm 0.03$ & $5.20 \pm 0.06$ & $4.70 \pm 0.03$ \\
\hline & 3 & $6.50 \pm 0.06$ & $5.58 \pm 0.07$ & $6.80 \pm 0.08$ \\
\hline \multirow[t]{3}{*}{$\mathrm{TC}_{1}$} & 1 & $2.70 \pm 0.06$ & $2.20 \pm 0.05$ & $3.90 \pm 0.02$ \\
\hline & 2 & $4.60 \pm 0.01$ & $5.10 \pm 0.06$ & $6.30 \pm 0.04$ \\
\hline & 3 & $6.15 \pm 0.07$ & $5.50 \pm 0.06$ & $7.30 \pm 0.08$ \\
\hline \multicolumn{5}{|c|}{ Flavonoids (mg CEE/gDW) } \\
\hline $\mathrm{TC}$ & & $1.85 \pm 0.01$ & $0.71 \pm 0.04$ & $3.80 \pm 0.04$ \\
\hline \multirow[t]{3}{*}{$\mathrm{TC}_{0}$} & 1 & $1.70 \pm 0.01$ & $0.69 \pm 0.03$ & $1.68 \pm 0.02$ \\
\hline & 2 & $1.50 \pm 0.01$ & $0.78 \pm 0.04$ & $1.12 \pm 0.05$ \\
\hline & 3 & $1.30 \pm 0.01$ & $0.68 \pm 0.03$ & $0.97 \pm 0.06$ \\
\hline \multirow[t]{3}{*}{$\mathrm{TC}_{1}$} & 1 & $1.49 \pm 0.04$ & $0.68 \pm 0.02$ & $1.30 \pm 0.02$ \\
\hline & 2 & $1.40 \pm 0.07$ & $0.61 \pm 0.06$ & $0.87 \pm 0.06$ \\
\hline & 3 & $1.20 \pm 0.04$ & $0.60 \pm 0.05$ & $0.86 \pm 0.02$ \\
\hline
\end{tabular}

Values are mean $\pm \mathrm{SD}, \mathrm{n}=3$

Table 2: Reducing power of Mentha spp at different development periods.

\begin{tabular}{ccccc}
\hline Stage & Development period (month) & Mentha piperita PPR 611 & Menthaarvensis SH & Mentha spicata SPR 8 \\
\hline $\mathrm{TC}$ & & $1.7 \pm 0.03$ & $1.1 \pm 0.02$ & $2.4 \pm 0.02$ \\
$\mathrm{TC}_{0}$ & 1 & $1.6 \pm 0.02$ & $2.4 \pm 0.03$ & $0.8 \pm 0.01$ \\
& 2 & $2.3 \pm 0.02$ & $1.2 \pm 0.01$ & $2.4 \pm 0.02$ \\
& 3 & $2.2 \pm 0.06$ & $1.6 \pm 0.02$ & $2.4 \pm 0.03$ \\
$\mathrm{TC}_{1}$ & 1 & $0.9 \pm 0.01$ & $0.7 \pm 0.01$ & $1.0 \pm 0.02$ \\
& 2 & $1.5 \pm 0.01$ & $1.4 \pm 0.02$ & $1.6 \pm 0.03$ \\
& 3 & $1.8 \pm 0.02$ & $2.3 \pm 0.03$ & $2.4 \pm 0.05$ \\
\hline
\end{tabular}

Values are mean $\pm \mathrm{SD}, \mathrm{n}=3$

Concentration of ascorbic acid for $\Delta 1 \mathrm{OD}=1100(\mu \mathrm{g} / \mathrm{ml})$

$* * \mathrm{RRP}=$ Relative reduction potential

$=\frac{\text { concentration of ascorbicacidfor } \Delta 10 \mathrm{D}(\mu \mathrm{g} / \mathrm{ml})}{\text { concentratiion of extractfor } \Delta \mathrm{OD}(\mu \mathrm{g} / \mathrm{ml})}$

Table 3: Iron chelation properties of Mentha spp at different development periods.

\begin{tabular}{|c|c|c|c|c|}
\hline \multirow[b]{2}{*}{ Stage } & \multirow{2}{*}{ Development period (month) } & \multicolumn{3}{|c|}{ \% Fe-Chelation } \\
\hline & & Mentha piperita PPR 611 & Mentha Arvensis SH & Menthas spicata SPR 8 \\
\hline TC & & $28.96 \pm 2.21$ & $25.96 \pm 2.28$ & $43.60 \pm 3.26$ \\
\hline \multirow[t]{3}{*}{$\mathrm{TC}_{0}$} & 1 & $28.84 \pm 3.32$ & $23.83 \pm 2.21$ & $42.76 \pm 3.57$ \\
\hline & 2 & $19.77 \pm 1.16$ & $16.41 \pm 1.19$ & $40.16 \pm 3.98$ \\
\hline & 3 & $17.61 \pm 1.19$ & $10.09 \pm 1.06$ & $36.29 \pm 2.71$ \\
\hline \multirow{3}{*}{$\mathrm{TC}_{1}$} & 1 & $18.65 \pm 2.23$ & $22.11 \pm 2.26$ & $41.58 \pm 2.53$ \\
\hline & 2 & $8.44 \pm 0.98$ & $14.29 \pm 1.06$ & $33.2 \pm 2.73$ \\
\hline & 3 & $6.93 \pm 0.03$ & $8.67 \pm 1.02$ & $23.16 \pm 2.94$ \\
\hline
\end{tabular}

Values are mean $\pm \mathrm{SD}, \mathrm{n}=3$.

\section{Iron reducing power assay (Fe (III) to Fe (II))}

Different studies have indicated that the antioxidant effect is related to the presence of reductones (Yen and Duh 1993). Reductones are reported to be terminators of free radical chain reactions (Gordon 1990), thus, the antioxidant activity of a methanolic extractmay be related to its reductive activity. This was done by determining the reduction of ferricyanide to ferrocyanide by the extract. The ferrocyanide so formed was measured by converting it to ferri-ferrocyanide- a blue colored complex. All the TC extracts of different species of Mentha possessed the ability to reduce iron (III) and do so in a linear concentrationdependent fashion. Table 2 showed that of all the three species, SPR- 8 was the most effective in this regard. This matches well with the reported antioxidant potential of Mentha spp especially with respect to hydroxyl and nitric oxide radical scavenging potential (Akashdeep et al., 2011). Further, it is evident from the results that iron reducing potential of tissue culture derived plants $\left(\mathrm{TC}_{0}\right.$ and $\mathrm{TC}_{1}$ ) increased with developmental period. The increase in iron reducing activity over developmental period matched well with the increase in total phenols and flavonoids.

\section{Iron chelation}

Iron is the most common cofactor within the oxygen handling biological machinery and, specifically, lipid peroxidation of biological membranes is the main pathogenic mechanism of iron overload induced tissue damage (Bonkovsky 1991). An effective therapeutic approach can play a double role in reducing the rate of oxidation - one by sequestering and chelating cellular iron stores (Rothman et al., 1992) and other as radical trap (i.e., antioxidant activity). Since plants has shown antioxidant and free radical scavenging activity (Bridges and Hoffman 1986), the present study, primarily incorporates the in vitro iron chelation 
potency of Mentha. Free iron ions are responsible for the generation of free radicals. Thus iron chelation can be useful property to prevent the formation of free radical. Iron chelation properties of Mentha extracts at a concentration of $500 \mu \mathrm{g} / \mathrm{ml}$ was determined by its ability compete with ferrozine for iron ions in free solution. For this the extracts were incubated with ferrous ions and ferrozine. Un-chelated ferrous ions would react with ferrozine to give an intense purple-blue colour. From the absorbance of $\mathrm{Fe}^{2+}$-ferrozine complex formed in the presence and absence of extract, the percent chelation was determined. It is evident from the results (Table 3) that tissue culture raised Mentha plantlets of SPR 8 or tissue cultured derived plants found to have better iron chelation property in comparison to other two species. Moreover, TC PPR 611, SH and SPR 8 Mentha extracts were better in iron chelation in comparison to TC derived plants of respective species. Iron chelation activity of $\mathrm{TC}$ derived plant samples $\left(\mathrm{TC}_{0}\right.$ and $\left.\mathrm{TC}_{1}\right)$ decreased over the growth period. Moreover, antioxidant can prevent the activity of free radicals either by scavenging or by inhibiting the free radicals. So a plant having both the iron chelating and iron reducing activityis more preferable a plant having one of these activities. The mentha plant has both these activities (Akbar et al., 2014). Iron is known to generate free radicals through the Fenton and Haber-Weiss reaction (Halliwell and Gutteridge 1990). It is an extremely reactive metal and catalyzes oxidative changes in lipids, proteins and other cellular components (Smith et al., 1992). Metal ion chelating activity of an antioxidant molecule prevents oxyradical generation and the consequent by oxidative damage. Likewise, it is reported that the metal ion chelating capacity of the phenols and polyphenols plays a significant role in reducing the concentration of the catalyzing transition metal in lipid peroxidation and stabilizing the oxidized form of the metal ion (Duh et al., 1999, Gordon 1990). Thus the higher degree of iron chelation by methanolic extracts of SPR 8 Mentha spp, proves its usefulness.

\section{CONCLUSION}

Based on the above mentioned results, it was concluded that the variation in total phenolic and flavonoid content in tissue cultured and tissue culture derived plantlets can be due to culture induced variations in biosynthetic pathways. Also, the iron reducing and iron chelation property was found to be better in Mentha Spicata sps. Iron reducing property increased with increase in growth period, however the iron chelation decreased with increase in development period for three months. Also the application of tissue culture techniques in conserving and augmentation of secondary metabolites in Mentha spp was evident from the results.

\section{Financial support and sponsorship: Nil.}

Conflict of Interests: There are no conflicts of interest.

\section{REFERENCES}

Akash Deep, Rana P, Gosal SS, Soni G. In vitro lipid peroxidation of tissue cultured and tissue culture derived Mentha plant. J Appl Pharma Sci, 2014; 4 (6): 079-083

Akash Deep, Rana P, Soni G.Effect of cultural manipulations on antioxidant potential of tissue cultured Mentha spicata (SPR 8). JPharm Res,2011;4(10):3368-3371

Akbar Dara M, Mubashir H, Masoodia, Adil F Walia, Mudasir A. Mira, Nida S. Antioxidant potential of methanol Root extract of Mentha arvensis L. from Kashmir Region. J Appl Pharma Sci, 2014; 4 (03): 050-057

Alsabri SG, El-Basir HM, Rmeli NB, Mohamed SB, Allafi AA, Zetrini AA, Salem AA, Mohamed SS, Gbaj A, El-Baseir. Phytochemical screening, antioxidant, antimicrobial and anti-proliferative activities study of Arbutus pavarii plant. J Chem Pharm Res, 2013; 5(1): 32-36. 301:32-43

Bonkovsky HL. Iron and the liver. Am J Med Sci, 1991;

Borneo R, Leon EA, Aguirre A, Ribotta P, Cantero JJ. Antioxidant capacity of medicinal plants from the Province of Cordoba (Argentina) and there in vitro testing in model food system. Food Chem, 2008; 112: 664-670.

Bridges KR, Hoffman KE. The effects of ascorbic acid on the intracellular metabolism of iron and ferritin. J Biol Chem, 1986; 261:14273-14277.

Cai YZ, Sun M, Xing J, Luo Q, Corke H. Structure-radical scavenging activity relationships of phenolic compounds from traditional Chinese medicinal plants. Life Sci, 2006; 78: 2872-2888.

Chang C, Yang M, Wen H, Chern J. Estimation of total flavonoid content in propolis by two complementary colorimetric methods. J.Food Drug Anal.,2002;10: 178-182.

Choudhury RP, Kumar A, Garg AN. Analysis of Indian mint (Mentha spicata) of essential, trace and toxic elements and its antioxidant behaviour. J Pharma Biomed Analysis, 2006; 41: 825-832.

Dinis TCP, Mudeira VMC, Almeida LM. Action of phenolics derivates (acetoaminophen, salicylate, and 5-aminosalicylate) as inhibitors of membrane lipid peroxidation and as peroxyl radical scavengers. Arch Biochem, 1994; 315: 161-169.

Dragland S, Senoo H, Wake K, Holte K, Blomhoff R. Several culinary and medicinal herbs are important sources of dietary antioxidants.JNutr, 2003; 133: 1286-1290.

Duh PD, Tu YY and Yen GC. Antioxidant activity of water extract of Harng Jyur (Ghrysanthemum morifolium Ramat). LWT, 2003;32: 269-277.

Ebrahimzadeh MA, Hosseinimehr SJ, Hamidinia A, Jafari M. Antioxidant and free radical scavenging activity of Feijoa sallowiana fruits peel and leaves. Pharmacologyonline, (2008a); 1: 7-14.

Ebrahimzadeh MA, Pourmorad F, Hafezi S Antioxidant Activities of Iranian corn silk. Turk. J. Biol, 2008b; 32: 43-49.

Ganesh CJ, Manjeshwar SB. Influence of the leaf extract of Mentha arvensis L.Linn. (mint) on the survival of Mice exposed to different doses of Gamma Radiation. Strhlenther Onkol, 2002; 178: 91-98.

Gordon MH.1990. The mechanism of antioxidant action in vitro. In: Food Antioxidants. Hudson B J F (ed). Pp 1-18. Elsevier Applied Science, London, UK.

Grul'ová DP, Labun F, Šeršeň I. Šalamon Seasonal Variation In DPPH Scavenging Activity Of Mentha Piperita. Advances in Environmental Biol, 2012;6(4): 1477-1480.

Halliwell B, Gutteridge JMC. Role of free radicals and catalytic metal ions in human disease: an overview. Meth Enzymol, 1990; 186: 1 85 .

Halliwell B, Rafter J, Jenner A. Health promotion by flavonoids, tocopherols, tocotrienols, and other phenols: direct or indirect effects? Antioxidant or not? Am J Clin Nutr, 2005;81: 268-276. 
Hossain MA, Nagooru MR. Biochemical profiling and total flavonoids and contents of leaves crude extract of endemic medicinal plants Corydyline terminalis L Kunth. Pharmacognosy Journal, 2011; 3(24): 25-29.

Julia, K., Claudia J. Draught, salt, temperature stress induced metabolic rearrangements and regulatory networks. J Expt Bot, 2012;63: $1593-1608$.

Kanatt SR, Chander R, Sharma A. Antioxidant potential of mint (Mentha spicataL.) in radiation-processed lamb meat. Food Chem,2007; 100: 451-458.

Katalinic V, Milos M, Kulisic T, Jukic M. Screening of 70 medicinal plant extracts for antioxidant capacity and total phenols. Food Chem, 2004; 94: 550-557.

Kumar A, Chattopadhyay S. DNA damage protecting activity and antioxidant potential of pudina extract. Food Chem,2007; 100: 13771384.

Lawrence BM, Mint: The Genus Mentha. CRC Press, 2006.

Liu X, Zhao M, Wang J, Yang B, Jiang Y. Antioxidant activity of methanolic extract of emblica fruit (Phyllanthus emblica L.) from six regions in China. J Food Compos Anal, 2008; 21(3): 219-228.

Lu Y., Foo LY. Foo Polyphenolics of Salvia: A review. Phytochemistry, 2002; 59: 117-140.

Manosroi J, Dhumtanom P, Manosroi A. Anti-proliferative activity of essential oil extracted from Thai medicinal plants on $\mathrm{KB}$ and P388 cell lines. Cancer Letter,2006; 235: 14-120

Marta C, Teixeira D, Glyn Mara F. Anti-candida activity of Brazilian medicinal plants. J Ethanopharmacol, 2005; 97: 305-311.

Mira L, Fernandez, MT, Santos, M, Rocha R, Florencio MH. Jennings KR. Interactions of flavonoids with iron and copper ions: A mechanism for their antioxidant activity. Free Radical Res, 2002; 36: 1199-1208.

Murashige T, Skoog F. A revised medium for rapid growth and bioassays with tobacco tissue cultures. Physiol Plant, 1962;15: 473-497.

Naghibi F, Mosaddegh M, Motamed S, Ghorbani A. "Labiatae Family in folk Medicine in Iran: from Ethnobotany to Pharmacology." Iran. J. Pharm. Res, 2005; 2: 63-79

Namiki M.Antioxidants/antimutagens in food. Crit Rev Food Sci Nutr, 1990; 29(4):273-300

Oyaizu M. Studies on products of browning reaction: Antioxidative activity of products of browning reaction. Jpn J Nutr, 1986;44: 307-315.

Payet B, Sing ASC, Smadja J. Assessment of antioxidant activity of cane brown sugars by ABTS and DPPH radical scavenging assays: determination of their polyphenolic and volatile constituents. J Agric Food Chem,2005; 53: 10074-10079.

Rothman RJ, Serroni A, Farber JL. Cellular pool of transient ferric iron, chelatable by deferoxamine and distinct from ferritin, that is involved in oxidative cell injury. Mol Pharmacol, 1992; 42:703-710.

Saidu AN, Mann A, Onuegbu CD. Pytochemical screening and hypoglycemic effect of aqueous Blighia sapida root bark extract on normoglycemic albino rats. Bri J Pharmaceu Res, 2012; 2: 89-97.
Saleem M, Alam A, Sultana S. Attenuation of benzoyl peroxide-mediated cutaneous oxidative stress and hyperproliferative response by the prophylactic treatment of mice with spearmint (Mentha spicata). Food and Chemical Toxicol, 2000; 38: 939-948.

Sasikumar JM, Maheshu V, Aseervatham GSB, Darsini DTP. In vitro antioxidant activity of Hedyotis corymbosa (L) Lam aerial plants. Indian J Biochem and Biophy, 2010; 47: 49-52.

Scherer R, Godoy HT. Antioxidant activity index (AAI) by the 2, 2-diphenyl-1 picrylhydrazyl method. Food Chem, 2009;112:654-658.

Sharififar F, Nudeh-Dehghn G, Mirtajaldini M. Major flavonoids with antioxidant activity from Teucrium polium L. Food Chem, 2008; 112: 885-888.

Smith C, Halliwell B, Aruoma OI. Protection by albumin against the pro-oxidant actions of phenolic dietary components. Food Chem Toxicol, 1992; 30: 483-489.

Suresh SN, Nagarajan N. Preliminary phytochemical and antimicrobial activity analysis of Begonia malabarica Lam. J. BasicAppl Biol, 2009; 3(1\&2): 59-61.

Tisserat B, Vaughn, S. Growth, morphogenesis and essential oil production in Mentha spicata L. shoots in vitro. In vitro Cell Dev Biol, 2008; 44: 40-50.

Tognolini M, Barocelli E, Ballabeni V, Bruni R, Bianchi A, Chiavarini M, Impicciatore M. Comparative screening of plant essential oils: Phenylpropanoid moiety as basic core for antiplatelet activity. Life Sciences, 2006; 78: 1419-1432

Tosun M, Ercisli S, Sengul M, Ozer H, Polat T. Antioxidant properties and total phenolic content of eight Salvia spp from Turkey.Biol Res, 2009; 41: 175-181.

Yaamamura S, Ozawa K, Ohatani K, Kasai R, Yamasaki K. Antihistaminic flavones and aliphatic glycosides from Mentha spicata. Phytochemistry, 1998; 48: 131-136.

Yen GC and Duh PD. Antioxidative properties of methanolic extracts from peanut hulls. J Am Oil Chem Soc, 1993; 70: 383-386.

$\mathrm{Yu} \mathrm{T}, \mathrm{Xu} \mathrm{M}$, Dashwood RH. Antimutagenic activity of Spearmint. Environmental and Molecular Mutagenesis,2004; 44: 387-393.

How to cite this article:

Deep A, Rana P, Soni G. Iron Chelation and Iron Reducing Activity of Tissue Cultured and Tissue Culture Derived Mentha Spp. J App Pharm Sci, 2017; 7 (05): 078-083. 